\title{
分子时代产前篮查和产前诊断技术和理念的变迁 及发展
}

\author{
戚庆炜, 周希亚, 蒋宇林, 吕嬿, 刘俊涛 ${ }^{*}$ \\ 中国医学科学院\&北京协和医学院, 北京协和医院产科中心, 北京 100730 \\ *联系人, E-mail: 13901365269@163.com \\ 收稿日期: 2021-04-26; 接受日期: 2021-06-23; 网络版发表日期: 2021-08-16
}

摘要最初的产前诊断主要针对染色体非整倍体, 随着遗传学检测技术的进展, 越来越多的遗传性疾病可以在产 前得到诊断, 包括致病性拷贝数变异、单基因病、单亲二体等, 产前遗传学检测从细胞遗传学时代进入到分子时 代. 随着 cfDNA(cell-free DNA)检测迅速整合进入产前篮查领域, 产前篎查也从基于生化指标的母血清学篎查时 代进入到分子时代, 很多单基因遗传病也可以通过扩展型携带者篮查被检出. 技术的进步极大地促进了学科的发 展，同时也极大地改变了人们的理念以及对产前篮查和产前诊断的认知.

关键词产前篮查, 产前诊断, 染色体非整倍体, cfDNA检测, 染色体微阵列分析, 外显子测序, 孕妇高龄

最初的产前诊断主要针对染色体非整倍体，随着 遗传学检测技术的进展，越来越多的遗传性疾病可以 在产前得到诊断，包括致病性拷贝数变异(copy number variant, $\mathrm{CNV}$ )、单基因病、单亲二体(uniparental disomy，UPD)等，产前遗传学检测从细胞遗传学时代 进入到分子时代. 随着游离DNA(cell-free DNA, cfDNA)检测迅速整合进入产前笁查领域，产前笁查也 从基于生化指标的母血清学篮查时代进入到分子时 代，很多单基因遗传病也可以通过扩展型携带者篮查 被检出．技术的进步极大地促进了学科的发展，同时 也极大地改变了人们的理念以及对于产前篮查和产前 诊断的认知. 本文拟从检测技术发展的角度出发, 对产 前篮查和产前诊断的认知和理念的变迁进行阐述和 评价.

\section{1 产前篮查的发展}

产前篎查遵循的原则是在Wilson和Junger提出的 篮查十大原则基础上完善而成的 ${ }^{[1]}$. 对目标疾病而言, 所篮查疾病应具有重要的临床意义, 定义明确, 对公 共健康具有重要影响; 对寿命或生活质量影响显著; 自然病史中存在无症状期, 使发现疾病成为可能; 通 过在无症状期识别或治疗疾病，结局能够得到改善. 对篮查性检测而言，其本身应当安全、可被接受; 足 够敏感和特异，能够检出疾病并使假阳性率降至最低; 效价比高. 对被篮查的人群而言, 目标疾病的患病率应 足够高; 所有人能够公平地得到检测和治疗; 检出的患 者愿意接受进一步的诊断或治疗 ${ }^{[2]}$. 基于上述原则, 产 前篮查的目标疾病从最初的开放性神经管缺陷(neural

引用格式: 戚庆炜, 周希亚, 蒋宇林, 等. 分子时代产前篮查和产前诊断技术和理念的变迁及发展. 中国科学: 生命科学, 2021, 51: 997-1006 Qi Q W, Zhou X Y, Jiang Y L, et al. Development of the technologies and cognition of prenatal screening and prenatal diagnosis in an era of molecular genetics (in Chinese). Sci Sin Vitae, 2021, 51: 997-1006, doi: 10.1360/SSV-2021-0128 
tube defect, NTD), 到胎儿常见染色体非整倍体、单基 因病, 至今已历经 40 余年(图1).

\section{1 开放性神经管缺陷}

1970年代，英国开展了针对甲胎蛋白 $(\alpha$-fetoprotein, AFP)的多中心协作研究 ${ }^{[3]}$, 发现在孕 16 18周, 怀 有无脑儿的孕妇血清AFP水平显著升高, 由此, 针对开 放性NTD的中孕期母血清AFP篮查成为第一个产前篮 查检测项目.

通过超声检查可以直接观察到胎儿脊柱，颖脑的 “柠檬征”和“香蕉征”则提示胎儿可能罹患脊柱裂。荟 萃分析发现，通过超声篎查脊柱裂的检出率为 $90 \%$ $\sim 95 \%$, 假阳性病例罕见 ${ }^{[4]}$. 另一方面, 围孕期补充叶酸 使得NTD的发病率大大降低，AFP篮查的阳性预测值 也随之下降. 越来越多的机构摒弃AFP篮查, 直接采用 超声篮查NTD.

\section{2 胎儿常见染色体非整倍体}

胎儿常见染色体非整倍体指的是 $21 、 13$ 和 18 三 体. 根据筛查原理的不同, 可将其分为 2 类: ( i ) 基于母 血清生化指标的产前笛查(maternal serum screening, MSS). (ii ) 基于胎儿cfDNA的产前篎查，即无创产前 检测(non-invasive prenatal testing, NIPT).

(1) MSS. 1984年, Merkatz等人 ${ }^{[5]}$ 发现, 怀有 21 三 体胎儿的孕妇血清AFP水平降低，由此开启了针对胎 儿21三体综合征的中孕期MSS，新的指标，如人线毛 膜促性腺激素(human chorionic gonadotrophin, hCG)、未结合雌三醇(unconjugated estriol, uE3)、抑
制素A(inhibin A)等不断被发现并纳入篮查方案, 诞生 了中孕期二联、三联、四联篮查方案. 1990年代, 英国 胎儿医学基金会发现，孕 $11 \sim 13^{+6}$ 周胎儿颈部透明层 (nuchal translucency, NT)增厚与胎儿非整倍体相关 ${ }^{[6]}$, 并将 $\mathrm{NT}$ 测量与早孕期母血清 $\mathrm{hCG}$ 、妊娠相关血浆蛋 白A(pregnancy associated plasma protein A, PAPP-A)检 测相结合进行早孕期筛查, 使检出率提升到 $86 \%$, 复合 假阳性率 $6.7 \%{ }^{[7]}$. 2000年后，国际上陆续开展SURUSS、FASTER等研究对早、中孕期MSS的不同策略 进行了系统评价 ${ }^{[8,9]}$. 结论显示, NT是最好的单个篮查 指标, 在双胎中具有与单胎相似的检出率. PAPP-A是 篮查效能最好的血清学指标. 在 $5 \%$ 假阳性率下, 早中 孕期整合篮查、分层篮查的检出率均可在 $90 \%$ 以上.

我国的MSS始于1998年前后，北京协和医院于 2008年牵头的多中心前瞻性研究, 获得了中国孕妇人 群 21 三体综合征篮查的数据库, 确定了各项篮查指标 的中位数值 ${ }^{[10]}$. 2010年, 原卫生部组织专家编写并颁 布了《胎儿常见染色体异常与开放性神经管缺陷的产 前笁查与诊断技术标准》，标志着中孕期MSS成为国 内开展最为广泛的服务模式. 2006年之后，随着NT篮 查的广泛开展，国内一些医疗机构开始进行早孕期篮 查或整合、分层篮查.

(2) cfDNA检测。1997年香港中文大学Lo等人 ${ }^{[11]}$ 首次报道在母血中含有胎儿源性的cfDNA片段，采用 二代测序(next-generation sequencing, NGS)技术, 结合 生物信息学分析, 即可篮查胎儿21、18、13三体. 2011 年, Chiu等人 ${ }^{[12]}$ 通过前瞻性研究证实该技术可用于胎 儿21三体的产前篮查，由此该项技术正式进入临床，
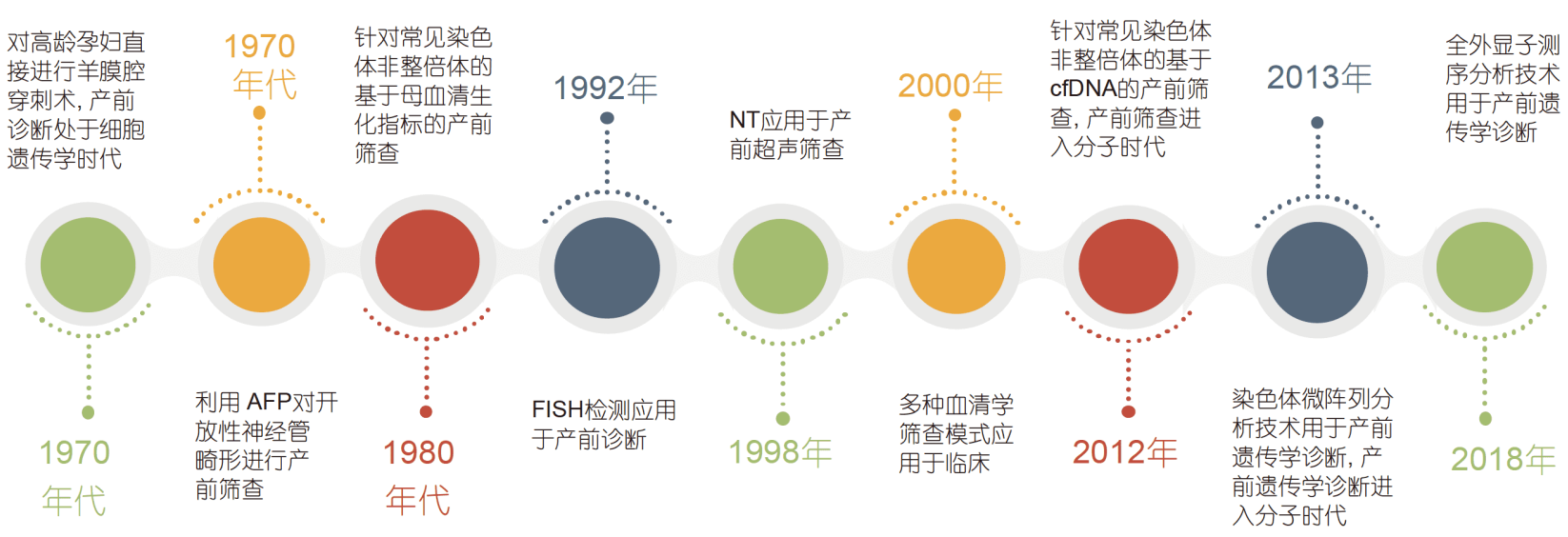

图 120 世纪70年代至今的产前䇻查与产前诊断技术变迁的时间轴线图

Figure 1 A timeline of changes in prenatal screening and prenatal diagnosis techniques from 1970s to the present 
并迅速地被整合进入产前篎查系统. 由于这些“胎儿源 性的cfDNA”来自胎盘细胞滋养细胞, 因此目前统一将 这一篮查方法称为 $c f D N A$ 检测.

早期的有关 $c f D N A$ 检测的研究大多基于高风险人 群 $^{[13 \sim 15]}$, 针对普通孕妇人群的前瞻性研究不多. 2013 年, 北京协和医院首次证实在低龄孕妇中, cfDNA检 测可取得与高龄、高风险孕妇相似的检测效力 ${ }^{[16]}$. 另 一项具有代表性的多中心大样本前瞻性研究来自Norton等人 ${ }^{[17]}$, 证实在普通人群中 cfDNA检测的篮查效率 显著优于MSS. 在上述研究的基础上, 美国医学遗传学 与基因组学学会(American College of Medical Genomics, ACMG)于2016年发布有关胎儿染色体非整倍体 无创产前篮查的共识 ${ }^{[18]}$, 明确指出 cfDNA检测是最敏 感的对于胎儿21、18、13 三体综合征产前篎查的技术 手段. 最近的荟萃分析 ${ }^{[19,20]}$ 显示, cfDNA检测对单胎妊 娠 $21 、 18 、 13$ 三体的检出率分别为 $99.7 \% 、 97.9 \%$ 、 $99.0 \%$ ，是目前最有效的、应用最广泛的胎儿常见染 色体非整倍体的产前篮查方法.

我国的cfDNA检测始于2011年，全国产前诊断专 家组以专家共识的形式在国际上率先提出 $\mathrm{cfDNA}$ 检测 的临床定位应为胎儿常见染色体异常的产前篮查技 术 $^{[21]}$. 此后, 通过2年的试点工作, 原国家卫生和计划生 育委员会办公厅于 2016 年组织全国产前诊断专家组编 写并发布了《孕妇外周血胎儿游离DNA产前篮查与 诊断技术规范》, 为该技术在我国规范、有序地开展 奠定了坚实的基础.

\section{3 单基因病的携带者篮查}

随着测序技术的发展，单基因病的携带者篮查逐 渐成为产前笚查的重要组成部分, 主要针对因认知和 身体残疾影响生活质量的疾病, 使预期寿命缩短的疾 病, 或通过药物、手术干预能够改善的疾病 ${ }^{[22]}$. 德系 犹太人自1971年起对Tay Sachs病进行携带者篮查, 使该病的发生率降低了 $90 \%$ 以上 ${ }^{[23]}$. 随着人口特征的 改变, 混合种族家庭越来越多, 对普通人群进行数十 甚至数百种基因病的扩展型携带者篎查(expanded carrier screening, ECS)的必要性越来越充分, NGS技 术的进展也使 $\mathrm{ECS}$ 从技术上成为可能. 由于缺乏基于 中国人群的设计良好的前瞻性研究, 以及被行业广泛 接受的共识或指南, 目前国内尚未在临床上开展 ECS.

\section{2 产前遗传学诊断技术的发展}

产前遗传学诊断是指利用线毛、羊水、脐血等样 本对胎儿遗传性疾病进行诊断. 随着遗传学技术的不 断发展, 产前诊断技术领域也历经细胞遗传学诊断、 细胞分子遗传学诊断和分子遗传学诊断三个阶段. 以 染色体微阵列分析(chromosomal microarray analysis, CMA) 和NGS技术为代表的分子遗传学诊断技术极大 地推动了染色体病和单基因病的产前诊断(图1).

(1) 细胞遗传学诊断. 从1970年代到2010年, 产前 遗传学检测基本上处于细胞遗传学阶段, 时至今日, $G$ 显带的染色体核型分析依然是产前细胞遗传学诊断的 金标准, 但细胞培养耗时长, 通常只能检出 $10 \mathrm{Mb}$ 以上 的片段改变.

(2) 细胞分子遗传学诊断. 细胞分子遗传学检测技 术的出现引入了快速产前诊断的概念, 主要技术包括 苂光原位杂交(fluorescence in situ hybridization, FISH) 和荧光定量PCR(quantitative fluorescence PCR, QFPCR), 用于快速检测胎儿13、18、21、性染色体有无 数目异常, 通常可在 $1 \sim 3$ 天获得结果, FISH与标准 $\mathrm{G}$ 显 带核型分析的一致性在 $99 \%$ 以上，敏感性、特异性和 预测值也都大于 $99 \%{ }^{[24,25]}$. QF-PCR 是对短串联重复序 列(short tandem repeats, STRs)进行PCR扩增, 通过定 性、定量分析STR的多态性来分析目标染色体有无数 目异常 ${ }^{[26-28]}$.

上述两项技术的优点是无需进行细胞培养, 分析 周期短, 尤其是QF-PCR检测, 通量高, 易于大规模开 展. 我国从1990年代末开始开展这两项技术, 作为产前 细胞遗传学诊断的补充检测, 有效地解决了产前诊断 技术服务能力不足、诊断周期长等现实问题. 但上述 技术也存在一定的局限性, 只能针对一定数目的片段 进行分析, 存在一定的残余风险, 无法检出这些染色 体的低水平嵌合、结构重排和标记染色体, 也不能提 供有关其他染色体的信息 ${ }^{[29,30]}$. 2015年, 我国产前诊 断技术专家组对这两项技术在国内应用存在的具体问 题进行了深入广泛的探讨, 并形成了其在产前诊断中 应用的专家共识 ${ }^{[31,32]}$.

(3) 分子遗传学诊断. 无论是细胞遗传学检测还是 分子细胞遗传学检测, 都存在局限性. 前者方法耗时、 分辨率低, 而后者又不能做到全局分析. CMA 检测能够 在全基因组水平上进行扫描, 可检出小于 $100 \mathrm{~kb}$ 大小的 
$\mathrm{CNV}$, 基本可以克服以上染色体分析技术的缺陷, 因此 又被称为“分子核型分析”。根据检测平台及其所检测 出的 $\mathrm{CNV}$ 类型的不同，CMA技术可被分为两大类：单 核苷酸多态性微列阵(single nucleotide polymorphism array, SNP array)和基于微阵列芯片的比较基因组杂交 (array-based comparative genomic hybridization, aCGH) 技术, 目前大多采用CNV+SNP两者结合的芯片.

2010年5月，国际细胞基因组芯片标准协作组(The International Standard Cytogenomic Array, ISCA Consortium)组织总结了21698例儿童遗传病的研究结果, 发现对于核型分析结果正常的病例，aCGH可检测出 $12.2 \%$ 的致病性 $\mathrm{CNV}$ ，从而推荐将 $\mathrm{aCGH}$ 作为对于未知 原因的发育迟缓、智力低下、多种体征畸形以及自闭 症的首选检测方法 ${ }^{[33]}$. CMA技术在儿童遗传病诊断领 域的成功应用, 使其很快就拓展到产前诊断领域 ${ }^{[3438]}$. 和传统的细胞遗传学检测相比, CMA检测最大的优势 在于能够检出更小的不平衡性改变、无需细胞培养、 自动化操作、快速得到结果. CMA在检出非整倍体方 面具有 $100 \%$ 的准确性，对于有临床指征而核型正常的

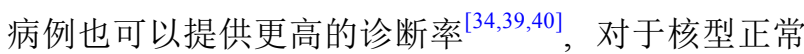
而超声发现胎儿结构异常的病例，CMA可以增加 $6 \%$ 的诊断率 ${ }^{[39]}$. 基于上述发现，2013年美国妇产科医师 协会(American College of Obstetrics and Gynecology, $\mathrm{ACOG})$ 的指南 ${ }^{[41]}$ 和 2014年国内的专家共识 ${ }^{[42]}$ 均提出, 对于产前超声结构异常的病例，应行包含CMA在内的 产前遗传学诊断. 鉴于对于超声和染色体核型都正常 的病例, CMA可以检出 $1.7 \%$ 的病理性 $\mathrm{CNV}^{[39]}$, ACOG 和美国母胎医学协会(Society for Maternal-Fetal Medicine, SMFM)在2016年发布实践指南, 进一步推荐对于 所有选择进行侵入性产前诊断的患者都进行CMA检 测 ${ }^{[43]}$. 2018年国际产前诊断协会(International Society for Prenatal Diagnosis, ISPD)、SMFM、围产质量基金 会(Perinatal Quality Foundation, PQF)发布的有关产前 DNA测序的联合申明, 将CMA列为对于超声发现胎儿 结构异常病例的产前标准遗传学诊断方法 ${ }^{[4]}$.

以外显子测序(exome sequencing, ES)技术为代表 的杂交捕获和高通量测序技术近年来在胎儿超声结构 异常的遗传学诊断领域得到应用. 根据检测范围的不 同, ES技术可分为全外显子测序(whole exome sequencing, WES)和临床外显子测序(clinical exome sequencing, CES)两大类. ES最初主要用于儿童遗传病的诊
断，Yang等人 ${ }^{[45,46]}$ 对 2000 个家系进行诊断性ES检测, 在 $25.2 \%$ 的病例中发现基因突变，从而奠定了ES检测 对于罕见孟德尔遗传单基因病的诊断价值. 和CMA检 测一样, ES技术在儿童遗传病诊断领域的成功应用，

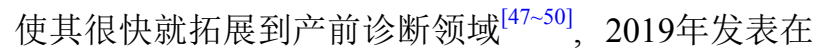
Lancet上的两篇分别来自欧洲和美国的两个大样本前 瞻性的、针对背景人群的研究显示, 当核型分析和 CMA检测均未有阳性发现的情况下, WES检测可检出 $10 \% \sim 12.5 \%$ 的单基因变异 ${ }^{[51,52]}$. 在上述研究基础上, 2020年ACMG发布指南，正式推荐对于超声发现胎儿 结构异常且核型分析和CMA检测结果正常的病例，应 进一步行ES检测以排除胎儿单基因变异 ${ }^{[53]}$.

近年来国内一些具备单基因病产前诊断基础的医 疗机构逐步开展WES检测，取得了良好的效果，预示 着该项技术在我国很快会进入产前诊断临床应用领 域 ${ }^{[54,55]}$.

\section{3 产前诊断指征的变迁和发展}

产前诊断通过羊膜腔穿刺术、线毛取样(chorionic villus sampling, CVS)或脐静脉穿刺术来获取样本. 随着实时超声引导技术的引入，侵入性产前诊断的操 作相关性流产风险也随之降低，2015年的一项荟萃分 析显示, CVS和羊膜腔穿刺的操作相关性流产风险分 别为 $1 / 450$ 和 $1 / 900^{[56]}$.

分子遗传学检测在临床的广泛应用使得人们的理 念和对产前诊断指征的认知随之发生改变, 主要体现 在以下三个方面: 孕妇高龄(advanced maternal age, AMA)、超声软指标、cfDNA检测发现的除21、13、 18 三体以外的其他染色体异常(以下简称cfDNA检测 的意外发现).

\section{$3.1 \quad$ AMA}

在分子遗传学检测应用于临床之前, AMA 是最常 见的产前诊断指征. 胎儿21、13、18 三体综合征的发 生率随孕妇年龄的增加而增加 ${ }^{[57 ~ 59]}$. 在1970年代, 标 准的产前保健措施是对AMA孕妇提供羊膜腔穿刺术 以检测胎儿是否存在染色体异常. 我国的《中华人民 共和国母婴保健法》明确规定，应对高龄初产妇进行 产前诊断. 随着AMA孕妇的不断增加和MSS的广泛开 展, 这一策略受到质疑 ${ }^{[60 \sim 65]}$. 
cfDNA检测的广泛应用极大地改变了人们对产前 篮查和诊断的认知. 2016年 $\mathrm{ACMG}$ 共识 ${ }^{[18]}$ 以及我国的 有关技术规范都明确指出，应告知所有孕妇， cfDNA 检测是最敏感的针对胎儿21、18、13 三体综合征的产 前篎查手段，AMA孕妇可以选择cfDNA检测，而无需 进行侵入性产前诊断. 孕妇年龄越大, cfDNA篮查的效 率越高, 以 21 三体为例, 在妊娠 10 周, 当孕妇年龄为 20、35、40岁时，cfDNA检测的阳性预测值(positive predictive value, PPV)分别为 $38 \% \sim 80 \% 、 73 \% \sim 95 \%$ 、 $91 \% \sim 99 \%$. 对于胎儿 $18 、 13$ 三体也是如此 ${ }^{[66]}$. 这些研 究结果更加说明对AMA孕妇采用cfDNA检测是有 益的.

与孕妇年龄相关的胎儿染色体异常类型只是 21 、 18 和13 三体综合征，胎儿性染色体非整倍体和致病性 $\mathrm{CNV}$ 的发生率与孕妇年龄无关 ${ }^{[39,67 \sim 69]}$. 系统性回顾和 荟萃分析研究结果显示, 36岁以下孕妇的胎儿致病性 $\mathrm{CNV}$ 的发生率高于 21 三体的发生率 ${ }^{[68]}$. 如果综合考虑 胎儿染色体异常(如整条染色体非整倍体、致病性 CNVs、UPD)的联合发生率, 当孕妇年龄为 20 岁时, 胎 儿染色体异常的联合发生率为 $1 / 122$, 当孕妇年龄为 40 岁时, 该发生率高达 $1 / 40^{[70]}$.

基于上述研究结果, ACOG在2020年发布关于胎 儿染色体异常的产前篮查指南 ${ }^{[70]}$, 指出任何孕妇都可 以选择进行 cfDNA检测或者是侵入性产前诊断，而无 论孕妇年龄多少岁, 如果选择后者, 则应进行包含 CMA检测在内的遗传学检测. 至此, 在学术层面上, 对 AMA永妇直接进行侵入性产前诊断的策略已被摒弃, AMA不再是侵入性产前诊断的指征.

\section{2 超声软指标}

产前超声异常包括胎儿结构异常和超声软指标. 前者往往由于胎儿遗传性疾病所致，其潜在机制包括 染色体异常、致病性 CNV、致病性单基因变异、 $\mathrm{UPD}$ 等, 此类病例已逐渐成为目前产前遗传学诊断最 主要的指征 ${ }^{[39,51,52,71 \sim 73]}$.

超声软指标指的是一些特殊的超声特征, 其临床 意义并不明确，常常为一过性，在晚孕期或出生后不 久即自然消退, 大多数胎儿并无不良结局, 但这些软 指标的存在与胎儿染色体异常和/或妊娠不良结局之 间有一定关联, 具有一定的统计学意义. 在 $c f D N A$ 检测 应用于临床之前, 超声软指标一度被认为是重要的侵
入性产前诊断指征. 事实上, 只有 $27 \%$ 的 21 三体胎儿在 中孕期超声检查中可以发现结构异常 ${ }^{[74]}$.2013年的一 篇荟萃分析认为, 大多数孤立性中孕期软指标对胎儿 21 三体前设风险的校正很有限 ${ }^{[75]}$. 如果孕妇 $\mathrm{cfDNA}$ 检 测结果为阴性, 漏诊 21 三体的可能性非常低, 在这种 情况下, 超声软指标对于 21 三体的预测价值非常有限.

CMA和ES检测技术在产前诊断领域的广泛应用 再次刷新了人们对超声篎查的价值的认识. 以NT为例, 起初NT被认为是胎儿 21 三体综合征的标记物, 进一步 研究发现, NT增厚和致病性CNV、某些遗传综合征以 及胎死宫内等不良妊娠结局密切相关 ${ }^{[76]}$. Choy等人 ${ }^{[77]}$ 对 50例NT $>3.5 \mathrm{~mm}$ 的病例进行基因组测序研究，32\% 的病例获得了遗传学诊断结果, 其类型包括染色体异 常、致病性CNV以及致病性单基因点突变. 他们指出, 对于NT增厚的病例, 应常规进行产前遗传学检测.

超声软指标还和妊娠不良结局具有相关性. Hurt 等人 ${ }^{[78,79]}$ 对Welsh地区2008 2011年所有产检孕妇的中 孕期系统胎儿超声检查的结果进行前瞻性研究, 对其 中具有超声软指标的病例进行追踪随访, 结果显示, 应结合既往胎儿染色体非整倍体篮查结果对超声软指 标者进行个性化分析, 应随访胎儿生长情况、胎盘功 能以及相关脏器的异常情况, 做出个性化的综合判断 和处理.

综合以往的研究结果, ACOG在2020年关于胎儿 染色体异常的篮查的指南对超声篮查的意义再次进行 总结 ${ }^{[70]}$, 指出应对NT增厚和颈部水囊瘤病例进行详细 的遗传咨询并提供产前遗传学检测. 该指南对中孕期 超声软指标的处理也列出了个性化处理方案. 这一指 南的发布, 对于超声软指标的临床处理策略具有很大 的指导意义.

\section{3 cfDNA检测的意外发现}

$\mathrm{cfDNA}$ 检测意外发现的发生率为 $0.12 \%$ $\sim 1.03 \%{ }^{[80-83]}$. 原因大致可以分为以下三类: (i) 胎儿 染色体异常; (ii) 局限性胎盘嵌合体(confined placental mosaicism, CPM); (iii) 母体CNV. 荷兰实验室的无 创产前检测的评估研究(Trial by Dutch laboratories for Evaluation of Non-Invasive Prenatal Testing, TRIDENT) ${ }^{[81]}$ 对 2527 例 $\mathrm{cfDNA}$ 检测结果为高风险而进行诊 断性检测的病例结果进行研究, cfDNA检测的意外发 现占全部产前诊断的 $1.6 \%$, 在这些意外发现的病例中, 
24.4\%为胎儿染色体异常, 53.6\%为胎盘染色体异常(其 中 $59.1 \%$ 合并胎儿先天性异常或者严重的生长受限), $2.4 \%$ 为母体染色体异常. 常家祯等人 ${ }^{[84]}$ 对在北京协和 医院进行 cfDNA检测的25334例结果进行回顾性分析, 意外发现的发生率为 $0.79 \%$, 其中 $70.8 \%$ 的病例为性染 色体非整倍体高风险，29.2\%的病例为罕见常染色体 三体高风险。上述研究结果显示, cfDNA检测的意外 发现并不少见，大部分病例都涉及到胎儿或胎盘的染 色体异常，应对此类病例进行侵入性产前诊断，并重 视妊娠结局随访.

\section{4 总结与展望}

综上所述, 随着遗传学检测技术的飞速发展, 无论
是产前笁查还是产前诊断领域，都从传统的细胞遗传 学时代进入到分子时代, 检测的目标疾病也从单一的 染色体非整倍体迅速扩展到致病性 CNV、单基因 病、UPD等领域, CMA检测已经成为标准遗传学检测. 技术的进步极大地改变了人们的理念以及对产前篮查 和产前诊断的认知, 以往的观点被重新评价, 有些观点 被摈弃. 强调每个孕妇都可以在知情同意的基础上选 择是否进行侵入性诊断性检测, 在学术层面上, 孕妇 高龄不再作为进行产前诊断的指标或依据. 在临床实 践中, 要充分做好对孕妇的检测前和检测后咨询, 详 细告知侵入性操作的并发症风险，各项遗传学检测技 术的性质、检测的目标疾病、局限性、检测周期、费 用, 由孕妇在知情同意的基础上根据自身意愿自行 选择.

\section{参考文献}

1 Raffle A E, Mackie A, Muir Gray, J A. How screening started. In: Screening: Evidence and Practice. 2nd ed. Oxford: Oxford University Press, 2019. 1-29

2 Cuckle H, Wald, N. Tests using single markers. In: Antenatal and Neonatal Screening. Oxford: Oxford University Press, 2005. 1-22

3 Wald N J, Cuckle H, Brock J H, et al. Maternal serum-alpha-fetoprotein measurement in antenatal screening for anencephaly and spina bifida in early pregnancy. Report of U.K. collaborative study on alpha-fetoprotein in relation to neural-tube defects. Lancet, 1977, 1: 1323-1332

4 Cuckle H, Thornton, J G. Antenatal diagnosis and management of neural tube defects. In: Fetal and Neonatal Neurology and Neurosurgery. London: Churchill Livingstone, 2014. 295-309

5 Merkatz I R, Nitowsky H M, Macri J N, et al. An association between low maternal serum $\alpha$-fetoprotein and fetal chromosomal abnormalities. Am J Obstet Gynecol, 1984, 148: 886-894

6 Pandya P P, Kondylios A, Hilbert L, et al. Chromosomal defects and outcome in 1015 fetuses with increased nuchal translucency. Ultrasound Obstet Gynecol, 1995, 5: 15-19

7 Spencer K, Spencer C E, Power M, et al. One stop clinic for assessment of risk for fetal anomalies: a report of the first year of prospective screening for chromosomal anomalies in the first trimester. Br J Obstet Gynecol, 2000, 107: 1271-1275

8 Wald N J, Rodeck C, Hackshaw A K, et al. First and second trimester antenatal screening for Down's syndrome: the results of the Serum, Urine and Ultrasound Screening Study (SURUSS). Health Technol Assess, 2003, 7: 1-77

9 Lambert-Messerlian G, Dugoff L, Vidaver J, et al. First- and second-trimester Down syndrome screening markers in pregnancies achieved through assisted reproductive technologies (ART): a FASTER trial study. Prenat Diagn, 2006, 26: 672-678

10 Bian X M, Liu J T, Qi Q W, et al. Second trimester maternal serum screening for Down's syndrome in mainland China: a multi-center prospective study (in Chinese). Chin J Obstet Gynecol, 2008, 43: 805-809 [边旭明, 刘俊涛, 戚庆炜, 等. 对孕中期妇女行血清学二联指标笁查胎儿唐氏 综合征的多中心前瞻性研究. 中华妇产科杂志, 2008, 43: 805-809]

11 Lo Y M D, Corbetta N, Chamberlain P F, et al. Presence of fetal DNA in maternal plasma and serum. Lancet, 1997, 350: 485-487

12 Chiu R W K, Chan K C A, Gao Y, et al. Noninvasive prenatal diagnosis of fetal chromosomal aneuploidy by massively parallel genomic sequencing of DNA in maternal plasma. Proc Natl Acad Sci USA, 2008, 105: 20458-20463

13 Palomaki G E, Kloza E M, Lambert-Messerlian G M, et al. DNA sequencing of maternal plasma to detect Down syndrome: an international clinical validation study. Genet Med, 2011, 13: 913-920

14 Bianchi D W, Platt L D, Goldberg J D, et al. Genome-wide fetal aneuploidy detection by maternal plasma DNA sequencing. Obstet Gynecol, 2012, 119: 890-901 
15 Song Y, Huang S, Zhou X, et al. Non-invasive prenatal testing for fetal aneuploidies in the first trimester of pregnancy. Ultrasound Obstet Gynecol, 2015, 45: 55-60

16 Song Y, Liu C, Qi H, et al. Noninvasive prenatal testing of fetal aneuploidies by massively parallel sequencing in a prospective Chinese population. Prenat Diagn, 2013, 33: 700-706

17 Norton M E, Brar H, Weiss J, et al. Non-Invasive Chromosomal Evaluation (NICE) Study: results of a multicenter prospective cohort study for detection of fetal trisomy 21 and trisomy 18. Am J Obstet Gynecol, 2012, 207: 137.e1

18 Gregg A R, Skotko B G, Benkendorf J L, et al. Noninvasive prenatal screening for fetal aneuploidy, 2016 update: a position statement of the American College of Medical Genetics and Genomics. Genet Med, 2016, 18: 1056-1065

19 Gil M M, Galeva S, Jani J, et al. Screening for trisomies by cfDNA testing of maternal blood in twin pregnancy: update of The Fetal Medicine Foundation results and meta-analysis. Ultrasound Obstet Gynecol, 2019, 53: 734-742

20 Gil M M, Accurti V, Santacruz B, et al. Analysis of cell-free DNA in maternal blood in screening for aneuploidies: updated meta-analysis. Ultrasound Obstet Gynecol, 2017, 50: 302-314

21 Jiang Y L, Zhu Y N, Lü S M, et al. Summary of 2012 expert symposium on the new molecular technogies in prenatal diagnosis (in Chinese). Chin J Obstet Gynecol, 2012, 47: 804-807 [蒋宇林, 朱宇宁, 吕时铭, 等. 2012年产前分子诊断新技术专家座谈会纪要. 中华妇产科杂志, 2012, 47: 804-807]

22 Edwards J G, Feldman G, Goldberg J, et al. Expanded carrier screening in reproductive medicine-points to consider: a joint statement of the American College of Medical Genetics and Genomics, American College of Obstetricians and Gynecologists, National Society of Genetic Counselors, Perinatal Quality Foundation, and Society for Maternal-Fetal Medicine. Obstet Gynecol, 2015, 125: 653-662

23 ACOG Committee Opinion No. 442: Preconception and prenatal carrier screening for genetic diseases in individuals of Eastern European Jewish descent. Obstet Gynecol, 2009, 114: 950

24 Pergament E, Xien Chen P, Thangavelu M, et al. The clinical application of interphase FISH in prenatal diagnosis. Prenat Diagn, 2000, 20: 215220

25 Tepperberg J, Pettenati M J, Rao P N, et al. Prenatal diagnosis using interphase fluorescence in situ hybridization (FISH): 2-year multi-center retrospective study and review of the literature. Prenat Diagn, 2001, 21: 293-301

26 Cirigliano V, Voglino G, Ordoñez E, et al. Rapid prenatal diagnosis of common chromosome aneuploidies by QF-PCR, results of 9 years of clinical experience. Prenat Diagn, 2009, 29: 40-49

27 Donaghue C, Roberts A, Mann K, et al. Development and targeted application of a rapid QF-PCR test for sex chromosome imbalance. Prenat Diagn, 2003, 23: 201-210

28 Hultén M A, Dhanjal S, Pertl B. Rapid and simple prenatal diagnosis of common chromosome disorders: advantages and disadvantages of the molecular methods FISH and QF-PCR. Reproduction, 2003, 126: 279-297

29 Qi Q W, Zhou X Y, Jiang Y L, et al. Residual risk of fetal cytogenetic abnomalities in interphase fluorescence in situ hybridization for amniocytes in second trimester: analysis of 2837 cases (in Chinese). Chin J Perinat Med, 2015, 18: 5-10 [戚庆炜, 周希亚, 蒋宇林, 等. 2837例妊娠中期孕 妇羊水间期细胞苂光原位杂交检测胎儿染色体异常的残余风险. 中华围产医学杂志, 2015, 18: 5-10]

30 Qi Q W, Hao N, Zhou J, et al. Evaluation of residual risk of cytogenetic abnomalities after prenatal diagnosis by interphase fluorescence in situ hybridization in second trimester: a retrospective analysis of conventional karyotyping on 6125 consecutive amniotic fluid specimens (in Chinese). J Reprod Med, 2015, 24: 429-435 [戚庆炜, 郝娜, 周京, 等. 羊水间期细胞苂光原位杂交检测残余风险评估:6125例产前细胞遗传 学诊断回顾性分. 生殖医学杂志, 2015, 24: 429-435]

31 Fluorescence In Situ Hybridization In Prenatal Diagnosis Workgroup. Expert consensus on application of flluorescence in situ hybridization in prenatal diagnosis (in Chinese). Chin J Obstet Gynecol, 2016, 51: 241-244 [苂光原位杂交技术在产前诊断中的应用协作组. 荧光原位杂交技 术在产前诊断中应用的专家共识. 中华妇产科杂志, 2016, 51: 241-244]

32 Quantitative Fluorescent Polymerase Chain Reaction In Prenatal Diagnosis Workgroup. Expert consensus on application of quantitative fluorescent polymerase chain reaction in prenatal diagnosis (in Chinese). Chin J Obstet Gynecol, 2016, 51: 321-324 [苂光定量PCR技术在产前 诊断中的应用协作组. 苂光定量PCR技术在产前诊断中的应用专家共识. 中华妇产科杂志, 2016, 51: 321-324]

33 Miller D T, Adam M P, Aradhya S, et al. Consensus statement: chromosomal microarray is a first-tier clinical diagnostic test for individuals with developmental disabilities or congenital anomalies. Am J Hum Genet, 2010, 86: 749-764

34 Breman A, Pursley A N, Hixson P, et al. Prenatal chromosomal microarray analysis in a diagnostic laboratory; experience with $>1000$ cases and 
review of the literature. Prenat Diagn, 2012, 32: 351-361

35 Schmid M, Stary S, Blaicher W, et al. Prenatal genetic diagnosis using microarray analysis in fetuses with congenital heart defects. Prenat Diagn, 2012, 32: 376-382

36 Leung T Y, Vogel I, Lau T K, et al. Identification of submicroscopic chromosomal aberrations in fetuses with increased nuchal translucency and apparently normal karyotype. Ultrasound Obstet Gynecol, 2011, 38: 314-319

37 Hillman S C, Pretlove S, Coomarasamy A, et al. Additional information from array comparative genomic hybridization technology over conventional karyotyping in prenatal diagnosis: a systematic review and meta-analysis. Ultrasound Obstet Gynecol, 2011, 37: 6-14

38 Shaffer L G, Dabell M P, Fisher A J, et al. Experience with microarray-based comparative genomic hybridization for prenatal diagnosis in over 5000 pregnancies. Prenat Diagn, 2012, 32: 976-985

39 Wapner R J, Martin C L, Levy B, et al. Chromosomal microarray versus karyotyping for prenatal diagnosis. N Engl J Med, 2012, 367: 2175-2184

Callaway J L A, Shaffer L G, Chitty L S, et al. The clinical utility of microarray technologies applied to prenatal cytogenetics in the presence of a normal conventional karyotype: a review of the literature. Prenat Diagn, 2013, 33: 1119-1123

41 Committee Opinion No. 581: the use of chromosomal microarray analysis in prenatal diagnosis. Obstet Gynecol, 2013, 122: 1374-1377

42 Chromosomal Microarray Analysis In Prenatal Diagnosis Workgroup. Expert consensus on application of chromosomal microarray analysis in prenatal diagnosis (in Chinese). Chin J Obstet Gynecol, 2014, 8: 570-572 [染色体微阵列分析技术在产前诊断中的应用协作组. 染色体微阵 列分析技术在产前诊断中的应用专家共识. 中华妇产科杂志, 2014, 8: 570-572]

43 Practice Bulletin No. 162 Summary: prenatal diagnostic testing for genetic disorders. Obstet Gynecol, 2016, 127: 976-978

44 The International Society for Prenatal Diagnosis, The Society for Maternal and Fetal Medicine, The Perinatal Quality Foundation. Joint Position Statement from the International Society for Prenatal Diagnosis (ISPD), the Society for Maternal Fetal Medicine (SMFM), and the Perinatal Quality Foundation (PQF) on the use of genome-wide sequencing for fetal diagnosis. Prenatal Diagn, 2018, 38: 6-9

45 Yang Y, Muzny D M, Reid J G, et al. Clinical whole-exome sequencing for the diagnosis of mendelian disorders. N Engl J Med, 2013, 369: $1502-1511$

46 Yang Y, Muzny D M, Xia F, et al. Molecular findings among patients referred for clinical whole-exome sequencing. JAMA, 2014, 312: 1870

47 Alamillo C L, Powis Z, Farwell K, et al. Exome sequencing positively identified relevant alterations in more than half of cases with an indication of prenatal ultrasound anomalies. Prenat Diagn, 2015, 35: 1073-1078

48 Westerfield L E, Stover S R, Mathur V S, et al. Reproductive genetic counseling challenges associated with diagnostic exome sequencing in a large academic private reproductive genetic counseling practice. Prenat Diagn, 2015, 35: 1022-1029

49 Kalynchuk E J, Althouse A, Parker L S, et al. Prenatal whole-exome sequencing: parental attitudes. Prenat Diagn, 2015, 35: 1030-1036

50 Best S, Wou K, Vora N, et al. Promises, pitfalls and practicalities of prenatal whole exome sequencing. Prenat Diagn, 2018, 38: 10-19

51 Lord J, McMullan D J, Eberhardt R Y, et al. Prenatal exome sequencing analysis in fetal structural anomalies detected by ultrasonography (PAGE): a cohort study. Lancet, 2019, 393: 747-757

52 Petrovski S, Aggarwal V, Giordano J L, et al. Whole-exome sequencing in the evaluation of fetal structural anomalies: a prospective cohort study. Lancet, 2019, 393: 758-767

53 Monaghan K G, Leach N T, Pekarek D, et al. The use of fetal exome sequencing in prenatal diagnosis: a points to consider document of the American College of Medical Genetics and Genomics (ACMG). Genet Med, 2020, 22: 675-680

$54 \mathrm{Fu} \mathrm{F}, \mathrm{Li} \mathrm{R}$, $\mathrm{Li} \mathrm{Y}$, et al. Whole exome sequencing as a diagnostic adjunct to clinical testing in fetuses with structural abnormalities. Ultrasound Obstet Gynecol, 2018, 51: 493-502

55 Qi Q, Jiang Y, Zhou X, et al. Simultaneous detection of CNVs and SNVs improves the diagnostic yield of fetuses with ultrasound anomalies and normal karyotypes. Genes, 2020, 11: 1397

56 Akolekar R, Beta J, Picciarelli G, et al. Procedure-related risk of miscarriage following amniocentesis and chorionic villus sampling: a systematic review and meta-analysis. Ultrasound Obstet Gynecol, 2015, 45: 16-26

57 Penrose L S. The relative effects of paternal and maternal age in mongolism. J Genet, 2009, 88: 9-14

58 Crider K S, Olney R S, Cragan J D. Trisomies 13 and 18: Population prevalences, characteristics, and prenatal diagnosis, metropolitan Atlanta, 1994-2003. Am J Med Genet, 2008, 146A: 820-826

59 Irving $\mathrm{C}$, Richmond $\mathrm{S}$, Wren $\mathrm{C}$, et al. Changes in fetal prevalence and outcome for trisomies 13 and 18: a population-based study over 23 years. $\mathrm{J}$ Matern Fetal Neonatal Med, 2011, 24: 137-141 
60 Dommergues M, Audibert F, Benattar C, et al. Is routine amniocentesis for advanced maternal age still indicated? Fetal Diagn Ther, 2001, 16: $372-377$

61 Benn P A, Egan J F X, Fang M, et al. Changes in the utilization of prenatal diagnosis. Obstet Gynecol, 2004, 103: 1255-1260

62 Hodges R J, Wallace E M. Testing for Down syndrome in the older woman: a risky business? Aust N Z J Obstet Gynaecol, 2005, 45: 486-488

63 Qi Q W, Jiang Y L, Liu J T, et al. Second trimester serum screening for Down's syndrome in women with advanced maternal age: a multi-center prospective study (in Chinese). Chin J Obstet Gynecol, 2008, 43: 737-741 [戚庆炜, 蒋宇林, 刘俊涛, 等. 对高龄孕妇于孕中期行血清学二联指 标篮查胎儿唐氏综合征的多中心前瞻性研究. 中华妇产科杂志, 2008, 43: 737-741]

64 Zhou X Y, Qi Q W, Jiang Y L, et al. Cost-effectiveness analysis of second trimester prenatal screening and diagnosis for fetal Down syndrome in women of advanced maternal age (in Chinsese). J Reprod Med, 2012, 21: 209-213 [周希亚, 戚庆炜, 蒋宇林, 等. 高龄孕妇胎儿唐氏综合征中 孕期产前篮查和产前诊断的卫生经济学分析. 生殖医学杂志, 2012, 21: 209-213]

65 Qi Q W, Jiang Y L, Zhou X Y, et al. Genetic counseling, prenatal screening and diagnosis of Down syndrome in the second trimester in women of advanced maternal age: a prospective study. Chin Med J, 2013, 126: 2007-2010

66 Hickok D E, Mills M. Percutaneous umbilical blood sampling: results from a multicenter collaborative registry. Am J Obstet Gynecol, 1992, 166: 1614-1618; discussion 7-8

67 Hook E B, Warburton D. The distribution of chromosomal genotypes associated with Turner's syndrome: livebirth prevalence rates and evidence for diminished fetal mortality and severity in genotypes associated with structural X abnormalities or mosaicism. Hum Genet, 1983, 64: 24-27 Srebniak M I, Joosten M, Knapen M F C M, et al. Frequency of submicroscopic chromosomal aberrations in pregnancies without increased risk for structural chromosomal aberrations: systematic review and meta-analysis. Ultrasound Obstet Gynecol, 2018, 51: 445-452

69 Forabosco A, Percesepe A, Santucci S. Incidence of non-age-dependent chromosomal abnormalities: a population-based study on 88965 amniocenteses. Eur J Hum Genet, 2009, 17: 897-903

70 Screening for Fetal Chromosomal Abnormalities: ACOG Practice Bulletin, Number 226. Obstet Gynecol, 2020, 136: e48-e69

71 de Wit M C, Srebniak M I, Govaerts L C P, et al. Additional value of prenatal genomic array testing in fetuses with isolated structural ultrasound abnormalities and a normal karyotype: a systematic review of the literature. Ultrasound Obstet Gynecol, 2014, 43: 139-146

72 Chen M, Chen J, Wang C, et al. Clinical application of medical exome sequencing for prenatal diagnosis of fetal structural anomalies. Eur J Obstet Gynecol Reprod Biol, 2020, 251: 119-124

73 Deden C, Neveling K, Zafeiropopoulou D, et al. Rapid whole exome sequencing in pregnancies to identify the underlying genetic cause in fetuses with congenital anomalies detected by ultrasound imaging. Prenatal Diagnosis, 2020, 40: 972-983

74 Bromley B, Lieberman E, Shipp T D, et al. The genetic sonogram: a method of risk assessment for Down syndrome in the second trimester. J Ultrasound Med, 2002, 21: 1087-1096

75 Agathokleous M, Chaveeva P, Poon L C Y, et al. Meta-analysis of second-trimester markers for trisomy 21. Ultrasound Obstet Gynecol, 2013, 41: $247-261$

76 Grande M, Jansen F A R, Blumenfeld Y J, et al. Genomic microarray in fetuses with increased nuchal translucency and normal karyotype: a systematic review and meta-analysis. Ultrasound Obstet Gynecol, 2015, 46: 650-658

77 Choy K W, Wang H, Shi M, et al. Prenatal diagnosis of fetuses with increased nuchal translucency by genome sequencing analysis. Front Genet, 2019, 10: 761

78 Hurt L, Wright M, Brook F, et al. The Welsh study of mothers and babies: protocol for a population-based cohort study to investigate the clinical significance of defined ultrasound findings of uncertain significance. BMC Pregn Childbirth, 2014, 14: 164

79 Hurt L, Wright M, Dunstan F, et al. Prevalence of defined ultrasound findings of unknown significance at the second trimester fetal anomaly scan and their association with adverse pregnancy outcomes: the Welsh study of mothers and babies population-based cohort. Prenat Diagn, 2016, 36: $40-48$

80 Ehrich M, Tynan J, Mazloom A, et al. Genome-wide cfDNA screening: clinical laboratory experience with the first 10,000 cases. Genet Med, 2017, 19: 1332-1337

81 Van Opstal D, van Maarle M C, Lichtenbelt K, et al. Origin and clinical relevance of chromosomal aberrations other than the common trisomies detected by genome-wide NIPS: results of the TRIDENT study. Genet Med, 2018, 20: 480-485

82 Scott F, Bonifacio M, Sandow R, et al. Rare autosomal trisomies: Important and not so rare. Prenat Diagn, 2018, 38: 765-771

83 Chatron N, Till M, Abel C, et al. Detection of rare autosomal trisomies through non-invasive prenatal testing: benefits for pregnancy 
management. Ultrasound Obstet Gynecol, 2019, 53: 129-130

84

Chang J Z, Zhou X Y, Qi Q W, et al. The prenatal diagnostic results of unexpected findings after non-invasive prenatal testing (in Chinese). J Dev

Med, 2020, 8: 220-226 [常家祯, 周希亚, 戚庆炜, 等. 无创产前检测意外发现的产前诊断结果分析. 发育医学电子杂志, 2020, 8: 220-226]

\title{
Development of the technologies and cognition of prenatal screening and prenatal diagnosis in an era of molecular genetics
}

\author{
QI QingWei, ZHOU XiYa, JIANG YuLin, LV Yan \& LIU JunTao \\ Department of Obstetrics and Gynecology, Peking Union Medical College Hospital, Chinese Academy of Medical Sciences \& Peking Union Medical \\ College, Beijing 100730, China
}

Original prenatal diagnostic testing focused primarily on chromosomal aneuploidies. Advances in genetics and genomic medicine have led to a dramatic increase in the availability of genetic testing, including in the prenatal period. Prenatal diagnosis is available for an ever-increasing number of disorders, including copy number variants, single gene disorders, and uniparental disomy. Prenatal genetic testing has stepped from the cytogenetic era into the molecular era. At the same time, prenatal screening has improved with development of cell-free DNA (cfDNA) screening, as well as expanded carrier screening for a broad array of inherited conditions. The advances in the technologies promote scientific research in this area and have altered people's cognition of prenatal screening and prenatal diagnosis.

prenatal screening, prenatal diagnosis, chromosomal aneuploidy, cfDNA testing, chromosomal microarray analysis, exome sequencing, advanced maternal age

doi: $10.1360 /$ SSV-2021-0128 